\title{
Allelopathy: How Plants Suppress Other Plants ${ }^{1}$
}

James J. Ferguson and Bala Rathinasabapathi ${ }^{2}$

\section{What is Allelopathy?}

Allelopathy refers to the beneficial or harmful effects of one plant on another plant, both crop and weed species, by the release of chemicals from plant parts by leaching, root exudation, volatilization, residue decomposition and other processes in both natural and agricultural systems.

First widely studied in forestry systems, allelopathy can affect many aspects of plant ecology including occurrence, growth, plant succession, the structure of plant communities, dominance, diversity, and plant productivity. Initially, many of the forestry species evaluated had negative allelopathic effects on food and fodder crops, but in the 1980s research was begun to identify forestry species that had beneficial, neutral, or selective effects on companion crop plants (Table 1). Early research grew out of observations of poor regeneration of forest species, crop damage, yield reductions, replant problems for tree crops, occurrence of weed-free zones, and other related changes in patterns of vegetation. Our purpose here is to introduce the concept of allelopathy, cite specific examples, and to mention potential applications as an alternative weed management strategy.

\section{Nature of Allelopathy}

Commonly cited effects of allelopathy include reduced seed germination and seedling growth. Like synthetic herbicides, there is no common mode of action or physiological target site for all allelochemicals. However, known sites of action for some allelochemicals include cell division, pollen germination, nutrient uptake, photosynthesis, and specific enzyme function.

Allelopathic inhibition is complex and can involve the interaction of different classes of chemicals like phenolic compounds, flavonoids, terpenoids, alkaloids, steroids, carbohydrates, and amino acids, with mixtures of different compounds sometimes having a greater allelopathic effect than individual compounds alone. Furthermore, physiological and environmental stresses, pests and diseases, solar radiation, herbicides, and less than optimal nutrient, moisture, and temperature levels can also affect allelopathic weed suppression. Different plant parts, including flowers, leaves, leaf litter and leaf mulch, stems, bark, roots, soil and soil leachates and their derived compounds, can have allelopathic activity that varies over a growing season. Allelopathic chemicals can also persist in soil, affecting both neighboring plants as well as those

1. This document is HS944, one of a series of the Horticultural Sciences Department, Florida Cooperative Extension Service, Institute of Food and Agricultural Sciences, University of Florida. Publication date: July 2003. Please visit the EDIS Web site at http://edis.ifas.ufl.edu.

2. James J. Ferguson, professor, Bala Rathinasabapathi, associate professor, Horticultural Sciences Department, Cooperative Extension Service, Institute of Food and Agricultural Sciences, University of Florida, Gainesville, 32611. 
planted in succession. Although derived from plants, allelochemicals may be more biodegradable than traditional herbicides but may also have undesirable effects on non-target species, necessitating ecological studies before widespread use.

Selective activity of tree allelochemicals on crops and other plants has also been reported. For example, Leucaena leucocephala, the miracle tree promoted for revegetation, soil and water conservation and animal improvements in India, also contains a toxic, non-protein amino acid in leaves and foliage that inhibits the growth of other trees but not its own seedlings. Leucaena species have also been shown to reduce the yield of wheat but increase the yield of rice. Leachates of the chaste tree or box elder can retard the growth of pangolagrass but stimulate growth of bluestem, another pasture grass.

Allelochemical concentrations in the producer plant may also vary over time and in the plant tissue produced. Foliar and leaf litter leachates of Eucalyptus species, for example, are more toxic than bark leachates to some food crops.

\section{Research Strategies and Potential Applications}

The basic approach used in allelopathic reseach for agricultural crops has been to screen both crop plants and natural vegetation for their capacity to suppress weeds. To demonstrate allelopathy, plant origin, production, and identification of allelochemicals must be established as well as persistence in the environment over time in concentrations sufficient to affect plant species. In the laboratory, plant extracts and leachates are commonly screened for their effects on seed germination with further isolation and identification of allelochemicals from greenhouse tests and field soil, confirming laboratory results. Interactions among allelopathic plants, host crops and other non-target organisms must also be considered. Furthermore, allelochemistry may provide basic structures or templates for developing new synthetic herbicides. Incorporation of allelopathic traits from wild or cultivated plants into crop plants through traditional breeding or genetic engineering methods could also enhance the biosynthesis and release of allelochemicals.
An allelopathic crop can potentially be used to control weeds by planting a variety with allelopathic qualities, either as a smother crop, in a rotational sequence, or when left as a residue or mulch, especially in low-till systems, to control subsequent weed growth. Alternatively, application of allelopathic compounds before, along with, or after synthetic herbicides could increase the overall effect of both materials, thereby reducing application rates of synthetic herbicides.

\section{References}

Kruse, M. M. Strandberg and B. Strandberg. 2000. Ecological Effects of Allelopathic Plants - A Review. National Environmental Research Institute NERI Technical Report No. 315. Silkeborg, Denmark.

Rizvi, S. J. H., M. Tahir, V. Rizvi, R. K. Kohli, and A. Ansari. 1999. Allelopathic Interactions in Agroforestry Systems. Critical Reviews in Plant Sciences 18: 773-779. 
Table 1. Examples of allelopathy from published research.

\begin{tabular}{||l|l||}
\hline \hline \multicolumn{1}{|c|}{ Allelopathic Plant } & \multicolumn{1}{|c||}{ Impact } \\
\hline $\begin{array}{l}\text { Rows of black walnut interplanted with corn in an } \\
\text { alley cropping system }\end{array}$ & $\begin{array}{l}\text { Reduced corn yield attributed to production of juglone, an } \\
\text { allelopathic compound from black walnut, found 4.25 meters from } \\
\text { trees }\end{array}$ \\
\hline $\begin{array}{l}\text { Rows of Leucaena interplanted with crops in an } \\
\text { alley cropping system }\end{array}$ & $\begin{array}{l}\text { Reduced the yield of wheat and tumeric but increased the yield of } \\
\text { maize and rice }\end{array}$ \\
\hline $\begin{array}{l}\text { Lantana, a perennial woody weed pest in Florida } \\
\text { citrus }\end{array}$ & $\begin{array}{l}\text { Lantana roots and shoots incorporated into soil reduced } \\
\text { germination and growth of milkweed vine, another weed }\end{array}$ \\
\hline $\begin{array}{l}\text { Sour orange, a widely used citrus rootstock in the } \\
\text { past, now avoided because of susceptibility to citrus } \\
\text { tristeza virus }\end{array}$ & $\begin{array}{l}\text { Leaf extracts and volatile compounds inhibited seed germination } \\
\text { and root growth of pigweed, bermudagrass, and lambsquarters }\end{array}$ \\
\hline $\begin{array}{l}\text { Red maple, swamp chestnut oak, sweet bay, and } \\
\text { red cedar }\end{array}$ & $\begin{array}{l}\text { Preliminary reports indicate that wood extracts inhibit lettuce seed } \\
\text { as much as or more than black walnut extracts }\end{array}$ \\
\hline Eucalyptus and neem trees & A spatial allelopathic relationship if wheat was grown within $5 \mathrm{~m}$ \\
\hline Chaste tree or box elder & $\begin{array}{l}\text { Leachates retarded the growth of pangolagrass, a pasture grass but } \\
\text { stimulated the growth of bluestem, another grass species }\end{array}$ \\
\hline Mango & $\begin{array}{l}\text { Dried mango leaf powder completely inhibited sprouting of purple } \\
\text { nutsedge tubers. }\end{array}$ \\
\hline Tree of Heaven & $\begin{array}{l}\text { Ailanthone, isolated from the Tree of Heaven, has been reported to } \\
\text { possess non-selecitve post-emergence herbicial activity similar to } \\
\text { glyphosate and paraquat }\end{array}$ \\
\hline Rye and wheat & $\begin{array}{l}\text { Allelopathic suppression of weeds when used as cover crops or } \\
\text { when crop residues are retained as mulch. }\end{array}$ \\
\hline Broccoli & $\begin{array}{l}\text { Broccoli residue interferes with growth of other cruciferous crops } \\
\text { that follow }\end{array}$ \\
\hline \hline
\end{tabular}

